ship lapsed, however, after Faraday's death. The other 'elected' professorship in the Institution at the time, that of natural philosophy, had been established ten years earlier, and was not so short-lived. It was created for Tyndall when he went to the Institution in 1853, and since his retirement in 1887 has con. tinued by election and re-election down to the present day. Sir James Jeans has thus been nominated to the first new professorship to be established in the Royal Institution for some seventy years. It is also the first chair of astronomy in the history of the Institution.

\section{Revision of Ordnance Survey Maps}

DURING last autumn, the council of the Chartered Surveyors' Institution decided to press for an official inquiry into the present position of the maps and plans of the Ordnance Survey, and an article on the subject appeared in Nature of November 3 (p. 677). In reply to a question by Sir Francis Fremantle in the House of Commons on April 1, Mr. Walter Elliot, Minister of Agriculture, said : "A substantial addition has been made to the Ordnance Survey Estimates for 1935 , and this will enable a beginning to be made in the way of overtaking arrears. I propose, however, to refer to a Departmental Committee the whole question of the acceleration of the revision of Ordnance Survey maps and the preparation of plans for town and country planning. I hope shortly to be able to announce the composition of the committee and its terms of reference."

\section{Model of the Rocket}

A FULL-SIZE replica of the locomotive Rocket, as originally designed and constructed by Robert and George Stephenson, has now been acquired for the National Collections in the Science Museum, and will be unveiled by Mr. L. Hore-Belisha, Minister of Transport, at noon on April 11. The model has been made by Messrs. Robert Stephenson and Co., the firm which built the original engine, and represents it, as nearly as possible, in form, materials and workmanship, as it originally appeared. The original engine was built to compete at the Rainbill Trials in October 1829, which was perhaps the most important event in early locomotive history. The success of Stephenson and Booth's Rocket, which won the premium of $£ 500$ offered by the directors of the Liverpool and Manchester Railway for the most improved locomotive engine constructed in accordance with certain conditions, definitely proved the suitability of the locomotive as a means of general railway haulage, and showed that speeds hitherto unapproached could be attained. The engine was entered by George and Robert Stephenson and Henry Booth. Its success was mainly due to the adoption of the tubular boiler, which was suggested to George Stephenson by Booth. While George Stephenson is popularly credited with the design of the Rocket, its actual construction, at Newcastle, was carried out by his son Robert, the father's time being fully occupied with the making of the railway itself.

\section{Co-operation between the Chemical Societies of Great} Britain

There has recently been circulated to all members of the Chemical Society, the Institute of Chemistry and the Society of Chemical Industry a draft agreement between the three Societies in regard to cooperation. The adoption of the agreement is unanimously recommended by the Council of the Society. of Chemical Industry and the draft agreement was published in Chemistry and Industry on March 15. The agreement provides for the establishment of a fund to be administered by a Chemical Council consisting of three members nominated by the Council of each Society, together with three representatives of industry, co-opted in the first instance on the nomination of the Association of British Chemical Manufacturers. The objects of the fund are the allocation of grants to the constituent bodies for the co-ordination of scientific publications, promotion of research, maintenance of a library, etc. Complete freedom of action is reserved to each constituent body in respect of the matter it publishes. The management of the library of the Chemical Society is delegated to a joint library committee, and contributions to the net annual maintenance expenditure are to be borne by the constituent bodies in proportion to their membership, with due allowance for overlap. This involves, for example, an increase in the contribution of the Institute of Chemistry to $£ 654$ and from the Society of Chemical Industry to £448. The agreement is for seven years and thereafter to continue for successive periods of three years, subject to right of withdrawal on giving one year's notice at the end of any period. If the agreement succeeds, it is anticipated that means of reducing subscriptions to the three organisations will be found.

\section{American Chemical Industry}

THE American Chemical Society is holding in conjunction with its annual meeting in New York on April 22, what may prove to be the largest scientific assembly in history. The object is to expound and commemorate the development of the American chemical industry since its foundation three hundred years ago by John Winthrop Jr., son of the pilgrim Governor of the Massachusetts Colony. In 1633 he set up in Boston the first chemical laboratory and library in the United States, for which he imported apparatus, chemicals and chemical books, and two years later when he became the first colonial Governor of Connecticut, he mapped out a far-reaching programme of local industries including the production of salt, iron, potash, tar, black lead, saltpetre, medicines, copper, alum and other chemicals. Some of these chemicals were made for local use; the chemicals of the forest were exported. It was at Winthrop's suggestion that Massachusetts passed a law in 1642 requiring every town to collect manures to make saltpetre. Chemical industry in the modern sense did not begin in the United States until 150 years later, when in 1792 the manufacture of sulphuric acid was commenced in Philadelphia by John Harrison. 
Since that time, the American chemical industry has not ceased to expand. In 1913-14 it produced 34 per cent by value - and much more by weight-of the world's chemical output; in 1923-24 this percentage had risen to 47 per cent. At the Congress it will be shown how the infant industries have become the bulwark of national defence, the basis of modern industrial progress and the source of an ever-growing percentage of national wealth. The honorary chairman of the New York Committee is Mr. Francis P. Garvan; the presidents of the great chemical companies are co-operating with the Society. At the chief symposium the outstanding addresses will be by T. Midgley on "Chemical Developments in the next 100 years", and W. B. Bell on "National Planning and the Chemical Industries". In addition, Senator Harrison will discuss economic aspects of the chemical industries in general. Mr. Lammot du Pont will deal with chemistry's sociological results and Senator Wadsworth will consider its importance in national integrity. The Congress will be divided into eighteen divisions ranging from foods to petroleum.

\section{Hydrogenation of Coal}

A Lecture by Dr. Pier before the Technischeliterarische Gesellschaft, Berlin, on the hydrogenation of coal, possesses an unusual importance in view of present interest in this subject and also in German efforts at national self-sufficiency. In Germany the first technical success was achieved in the hydrogenation of brown coal and tars produced therefrom. For several years large quantities of petrol have been produced from brown coal at the Leuna works of the I. G. Farbenindustrie A.G. Since 1932, interest has been directed to corresponding treatment of bituminous coal in the Ludwigshafen works of the I.G. Since last year, a plant capable of a daily throughput of 20 tons of coal has been working there, and it is the successful performance of this unit which forms the subject of Dr. Pier's paper. Actually, a somewhat similar plant has been in operation at the Billingham works of Imperial Chemical Industries, Ltd. since 1930 , and the large unit (500 tons daily) projected in 1933 will soon be brought into commission. The results of the German tests leave no doubts as to its success.

HXdRogenation reactions may take several forms, for example, in liquid phase with coal or oil, and in vapour phase with more volatile liquids. At Billingham the petrol is already being made from creosote oils in vapour phase units. The patent rights in these processes are held by the International Hydrogenation Patent Co., and since 1931 experience and information in these processes have been pooled by the I.G., Imperial Chemical Industries, Standard Oil and Shell Oil Companies. Although the literature of coal hydrogenation on the experimental scale is large, information about the construction and performance of manufacturing units has not hitherto been disclosed, and this lends added importance to Dr. Pier's paper. As a result of international co-operation for scientific and industrial purposes, the work stands in marked contrast to corresponding efforts in the political fields.

\section{Excavation of Norfolk 'Woodhenge'}

According to an announcement reported in The Times of March 29, preparations are being made by the Norfolk Research Committee, of which Mr. Russell J. Colman is president, to explore the site which, from its similarity to that on Salisbury Plain, has been called 'Woodhenge', at Arminghall, near Lakenham Baths, Norwich. The existence of this circle was first ascertained by observation from the air by the Royal Air Force, and certain preliminary examinations carried out soon after revealed the character of the site; but no systematic or extended excavation has as yet been attempted. The present operations will be under the supervision of Dr. Grahame Clark, of Peterhouse, Cambridge, and secretary of the Fenland Exploration Committee, and Mr. Rainbird Clark, honorary secretary of the Norfolk R ssearch Committee. The work will begin in August next and, it is hoped, will be completed when the British Association meets at Norwich in the following month.

\section{Jubilee of the Dublin Naturalists' Field Club}

The jubilee of the Dublin Naturalists' Field Club will be celebrated in Dublin on July 11-13 by a meeting of representative delegates from many of the natural history societies in Ireland and Great Britain, and probably from abroad. Formed fifty years ago with Prof. E. Perceval Wright as its first president, the man mostly responsible for the initiation of the Dublin Naturalists' Field Club was its vice-president, Dr. A. C. Haddon, the veteran anthropologist now at Cambridge. The formation of the Irish Field Club in 1894 brought the Society into closer touch with other natural history bodies in Ireland, while in 1892 it was largely responsible for forming the old Irish Naturalist as a monthly journal for the scientific recording of its and other societies' proceedings. Among the more notable workers of the Field Club in its history were G. H. Carpenter, the entomologist and mammalogist, for many years its president, as at the Galway Field Club conference of 1895 ; Dr. R. Lloyd Praeger, its secretary in late Victorian times, who wrote the flora section of the British Association Handbook for its Dublin meeting of 1908; and David McArdle, of Glasnevin, who wrote the section on mosses and lichens in the same handbook. Other prominent members of the Field Club in its early years were Prof. T. Johnson, its treasurer, Prof. E. J. M. M'Weeney of Dublin and Prof. G. F. Fitzgerald of Trinity College.

\section{Twelfth International Congress of Zoology}

IT is announced that the Twelfth International Congress of Zoology will be held at Lisbon on September 15-21 under the presidency of Prof. A. Ricardo Jorge, professor in the Faculty of Sciences in the University of Lisbon, and director of the Zoological and Anthropological Department of the National 